\title{
Does rise in temperature adversely affect soil fertility, carbon fractions, microbial biomass and enzyme activities under different land uses?
}

\author{
Dibyendu Chatterjee $^{1, *}$, Rukuosietuo Kuotsu ${ }^{1}$, Merasenla Ao ${ }^{1}$, Saurav Saha ${ }^{2}$, \\ Sanjay Kumar Ray ${ }^{1}$ and S. V. Ngachan ${ }^{3}$ \\ ${ }^{1}$ Indian Council of Agricultural Research, Research Complex for North Eastern Hill Region, Nagaland Centre, Jharnapani, \\ Medziphema 797 106, India \\ ${ }^{2}$ Indian Council of Agricultural Research, Research Complex for North Eastern Hill Region, Mizoram Centre, Kolasib 796081 , India \\ ${ }^{3}$ Indian Council of Agricultural Research, Research Complex for NEH Region, Umiam 793 103, India
}

We studied the variable dynamic response of different soil properties under the exposure of three elevated temperature treatments on six land-use systems. After one month of incubation, the associated changes were measured in terms of soil fertility, carbon, microbial biomass and soil enzymes. Our results confirmed the significant increase $(P<0.05)$ in soil available nitrogen content (by $1.85-49.32 \%$ ) with the subsequent rise in incubation temperature for soils collected from orchards and agriculture land uses. We observed a steady decrease in total organic carbon (TOC) levels with increase in incubation temperature varying between $4.1 \%$ and $31.4 \%(P<0.05)$ across different soil types and land-use systems, resulting in a significant rising trend for microbial biomass carbon and labile carbon : TOC ratio up to $3^{\circ} \mathrm{C}$ elevation from maximum temperature. Among the soil enzymes, dehydrogenase, fluorescein diacetate hydrolase and $\beta$-glucosidase activity increased significantly with increase in incubation temperature from the ambient temperature, while acid phosphomonoesterase and arylsulphatase activity decreased. Our current research findings will provide new insights regarding temperature control on soil $C$ dynamics and nutrient availability in terms of modified soil enzyme activity that will be useful to model the dynamics of soil organic matter and associated nutrient availability in acid soils.

Keywords: Carbon, land use, microbial biomass, soil enzyme activity, temperature effects.

IN the post-industrial revolution era, technological advancement of modern human civilization invades the obvious negative consequences of increasing anthropogenic greenhouse gas (GHG) emission with a significant atmospheric warming trend, worldwide. The level of atmospheric carbon dioxide $\left(\mathrm{CO}_{2}\right)$ is expected to reach

\footnotetext{
*For correspondence. (e-mail: dibyenducha@gmail.com)
}

about 570 ppm by 2050, with the concomitant increase in average global air temperature by $1.8-6.4^{\circ} \mathrm{C}$ by $2100 \mathrm{AD}$, depending on the emissions scenario in the next few dec$\operatorname{ades}^{1,2}$. This warming trend in India over the past 100 years $\left(\sim 0.6^{\circ} \mathrm{C}\right)$ is comparable to the increase in global mean temperature in the past 100 years ${ }^{3}$. Soils act as the major source and sink of carbon (C) that have the potential to sequester sizable quantities of atmospheric $\mathrm{CO}_{2}$, and soil $\mathrm{C}$ is a consequential necessity for maintaining soil fertility. The natural feedback mechanism of atmospheric warming mostly relies on two probable consequences for our warmer globe, viz. either significant $\mathrm{C}$ influx from atmosphere to soil that will reduce the net atmospheric $\mathrm{C}$ load and nullify the warming trend (negative feedback), or increase in heterotropic respiration that may further accelerate the warming process (positive feedback) ${ }^{4}$. The microbial decomposition process of soil organic matter (SOM) is highly sensitive to such a change in surrounding environmental condition (temperature increase), which has the potential to modify the enzyme kinetics and associated nutrient availability in the soil system through alteration in resource allocation strategy and community composition of the soil biota ${ }^{5,6}$. The modified dynamics of soil microbial activity in warmer environment may determine the effective direction and net magnitude of $\mathrm{C}$ flux among the source-sink components of the global carbon cycle as well as the status of soil $\mathrm{C}$ pools, available nutrient status and soil $\mathrm{C}$ stock that ultimately affect crop production ${ }^{7,8}$.

Land-use pattern and soil management factors have the key functional control on dynamics of soil $\mathrm{C}$ stock over the long run. Rabbi et al. ${ }^{9}$ reported that properties like soil texture, soil density and $\mathrm{pH}$ had robust associations with soil organic carbon (SOC) fractions under different land-use systems. Shrestha et al. ${ }^{10}$ and Saha et al. ${ }^{11}$ reported higher SOC stock status of surface soils in grasslands followed by forest and agricultural lands respectively, under the humid subtropical climate of the 
Himalaya for a wide range of soil $\mathrm{pH}$ values (varying from 4.7 to 6.9 ). Soil enzyme activities are useful to monitor changes in soil quality as well as nutrient availability to plants. Irrespective of the level of fertilizer application, intensification of land use from grasslands to agricultural lands yielded contrasting results of either increase ${ }^{12}$ or decrease ${ }^{13}$ in soil nutrient content with significant reduction in soil enzyme activities ${ }^{14}$. Mganga et al. ${ }^{15}$ observed that the traditional agroforestry systems promoted soil fertility with enhanced soil microbial biomass $\mathrm{C}$ and associated enzyme activities, than monocropping with agricultural crops (maize) for neutral to slightly acidic soils of tropical Africa. The beneficial role of minimum disturbance in different land-use systems enhanced soil enzyme activities involved in carbon, nitrogen, phosphorus, sulphur cycling ${ }^{14}$, that resulted in an increase in net nutrient availability for acid soils in different land-use systems (orchards, grasslands and agricultural land) of subtropical China ${ }^{16}$.

A literature survey showed that separate research efforts on studying the impact of either temperature or land-use systems on soil $\mathrm{C}$ stock status, enzyme activities and associated soil nutrient dynamics. Collective reporting for the effect of these two factors on the acid soils of humid subtropical regions of North East India is scarce ${ }^{17}$, as they are exclusively important to model the interaction mechanism between land use and global climate change ${ }^{18}$. There are large uncertainties and lack of knowledge on possible modification of the mechanistic link between microbial enzyme dynamics and associated nutrient pools as modified under elevated temperature exposure. Therefore, this research gap streamlined our present research objective of mechanistic evaluation of the effect of elevated temperature and different land-use systems on nutrient transformation, carbon dynamics, microbial biomass and enzymatic activities in the acid soils of Nagaland, NE India. Our result will enable us to identify potential land-use system(s) with high carbon accumulation potential with consequent rise in air temperature. Our hypothesis was that increase in incubation temperature would modify the soil biochemical properties that will affect the dynamics of soil carbon and storage of other nutrients through enhanced enzymatic activities that may negatively affect soil quality.

\section{Material and methods}

\section{Collection of soils from various land-use systems under different soil orders}

Composite soil samples $(0-15 \mathrm{~cm})$ were collected from six land-use systems distributed within two soil orders (Alfisols and Entisols) in three replications. The samples collected from various locations in Nagaland, varied widely in terms of elevation, system of cultivation and vegetation type. Table 1 provides details of the collected experimental materials and their properties.

\section{Incubation experiment at elevated maximum temperature}

We conducted a controlled incubation experiment at elevated temperatures in the ICAR Research Complex for NEH Region, Nagaland Centre, Medziphema, with the collected soil samples. For this, the composite soil samples were taken in a perforated container and kept in a petri plate containing distilled water. The soils were saturated overnight in an air-tight container to prevent evaporation loss, followed by draining out of excess water under gravitational pull to attain moisture content at field capacity. The soil samples were then transferred to a moistureproof container and maintained for one month at various temperatures in a BOD incubator. The highest value of mean monthly maximum temperature at the study site varied from $34.7^{\circ} \mathrm{C}(2011), 36.5^{\circ} \mathrm{C}(2012)$, and $35.7^{\circ} \mathrm{C}$ (2013) with an average of $35.6^{\circ} \mathrm{C}\left(\sim 36^{\circ} \mathrm{C}\right)$. Therefore, we selected a set of temperatures, viz. ambient temperature $\left(27^{\circ} \mathrm{C}\right)$, maximum temperature $\left(36^{\circ} \mathrm{C}\right), 3^{\circ} \mathrm{C}$ elevation from maximum temperature $\left(39^{\circ} \mathrm{C}\right)$, and $6^{\circ} \mathrm{C}$ elevation from maximum temperature $\left(42^{\circ} \mathrm{C}\right)$. The sealed containers were turned upside down daily, for uniform movement of water vapour inside the container. After a month, the entire soil samples were taken out from the incubation chamber and moist soils were used to analyse microbial biomass and soil enzymes; whereas for soil fertility and carbon fractions, processed air-dried soil samples were used.

\section{Soil analysis for fertility, carbon fractions, microbial biomass and enzyme activities}

The collected soil samples were air dried, ground and passed through $2 \mathrm{~mm}$ sieve to analyse soil $\mathrm{pH}$, electrical conductivity (EC), available nitrogen $(\mathrm{N})$, available phosphorus $(\mathrm{P})$, available potassium $(\mathrm{K})$ and oxidizable organic carbon, total organic carbon (TOC) and labile carbon (LC) under variable incubation temperature exposures. Fresh moist samples were used to determine microbial biomass carbon (MBC), microbial biomass nitrogen (MBN) and microbial biomass phosphorus (MBP), and the hydrolytic activities of different soil enzymes. $\mathrm{pH}$ in soil-water suspension $(1: 2.5)$ was measured using a combined electrode (glass and calomel) fitted with a digital $\mathrm{pH}$ meter. EC was measured in the supernatant liquid of the soil-water suspension $(1: 2.5)$ using conductivity bridge at $25^{\circ} \mathrm{C}\left(\mathrm{dS} \mathrm{m}^{-1}\right)$. Available nitrogen was measured by alkaline- $\mathrm{KMnO}_{4}$ method ${ }^{19}$. Available phosphorus was extracted following Bray-Kurtz No. 1 method $^{20}$, followed by the measurement of blue colour development using ascorbic acid method ${ }^{21}$. Available potassium was extracted by $1 \mathrm{~N}$ neutral $\mathrm{NH}_{4} \mathrm{OAc}$ and determined by flame photometer ${ }^{22}$. 
RESEARCH ARTICLES

Table 1. Details of experimental soil sample collection sites and properties of the collected soil

\begin{tabular}{|c|c|c|c|c|c|c|c|c|}
\hline Notation & Soil type & \multicolumn{2}{|c|}{ Vegetation } & \multicolumn{2}{|c|}{ System of cultivation } & Latitude $(\mathrm{N})$ & Longitude (E) & Elevation $(\mathrm{m})$ \\
\hline $\mathrm{AF}$ & Alfisol & \multicolumn{2}{|c|}{ Forest trees } & \multicolumn{2}{|c|}{ Natural forest } & $25^{\circ} 35^{\prime} 56.4^{\prime \prime}$ & $93^{\circ} 53^{\prime} 8.7^{\prime \prime}$ & 520.0 \\
\hline $\mathrm{AO}$ & Alfisol & \multicolumn{2}{|c|}{$\begin{array}{l}\text { Orchards with banana, } \\
\text { arecanut, mango, litchi } \\
\text { and jackfruit }\end{array}$} & \multicolumn{2}{|c|}{ Plantation ( 5 years old) } & $25^{\circ} 46^{\prime} 1.7^{\prime \prime}$ & $93^{\circ} 53^{\prime} 8.1^{\prime \prime}$ & 517.9 \\
\hline EA & Entisol & \multicolumn{2}{|c|}{ Rice-rice } & \multicolumn{2}{|c|}{ Wet rice cultivation ( 5 years old) } & $25^{\circ} 49^{\prime} 16.6^{\prime \prime}$ & $93^{\circ} 39^{\prime} 54.4^{\prime \prime}$ & 157.0 \\
\hline $\mathrm{EF}$ & Entisol & \multicolumn{2}{|c|}{ Forest (teak) } & \multicolumn{2}{|c|}{$\begin{array}{l}\text { Old forests are replaced by teak } \\
\qquad(>10 \text { years old })\end{array}$} & $25^{\circ} 49^{\prime} 15.6^{\prime \prime}$ & $93^{\circ} 39^{\prime} 59.4^{\prime \prime}$ & 159.0 \\
\hline $\mathrm{EO}$ & Entisol & \multirow{2}{*}{\multicolumn{2}{|c|}{$\begin{array}{l}\text { Orchard (banana) } \\
\text { Cynodon dactylon } \\
\quad \text { (major species) }\end{array}$}} & \multirow{2}{*}{\multicolumn{2}{|c|}{$\begin{array}{l}\text { Plantation }(2-3 \text { years }) \\
\text { Non-cultivated pasture land }\end{array}$}} & $25^{\circ} 49^{\prime} 15.9^{\prime \prime}$ & $93^{\circ} 40^{\prime} 6.3^{\prime \prime}$ & 161.0 \\
\hline EP & Entisol & & & & & $25^{\circ} 49^{\prime} 19.2^{\prime \prime}$ & $93^{\circ} 40^{\prime} 19.3^{\prime \prime}$ & 158.0 \\
\hline Notation & $\mathrm{pH}$ & $\begin{array}{c}\mathrm{EC} \\
\left(\mathrm{dS} \mathrm{m} \mathrm{m}^{-1}\right)\end{array}$ & $\begin{array}{l}\text { Available } \mathrm{N} \\
\left(\mathrm{kg} \mathrm{ha}^{-1}\right)\end{array}$ & $\begin{array}{l}\text { Available P } \\
\left(\mathrm{kg} \mathrm{ha}^{-1}\right)\end{array}$ & $\begin{array}{l}\text { Available } \mathrm{K} \\
\left(\mathrm{kg} \mathrm{ha}^{-1}\right)\end{array}$ & $\begin{array}{c}\mathrm{OC} \\
\left(\mathrm{g} 100 \mathrm{~g}^{-1}\right)\end{array}$ & $\begin{array}{c}\text { TOC } \\
\left(\mathrm{g} 100 \mathrm{~g}^{-1}\right)\end{array}$ & $\begin{array}{c}\mathrm{LC} \\
\left(\mathrm{g} 100 \mathrm{~g}^{-1}\right)\end{array}$ \\
\hline $\mathrm{AF}$ & 3.90 & 0.075 & 260.9 & 15.5 & 114.3 & 0.65 & 1.50 & 0.21 \\
\hline $\mathrm{AO}$ & 4.15 & 0.080 & 160.6 & 25.7 & 115.6 & 0.50 & 1.60 & 0.15 \\
\hline EA & 5.00 & 0.110 & 210.5 & 24.7 & 170.8 & 0.47 & 1.56 & 0.17 \\
\hline $\mathrm{EF}$ & 5.00 & 0.085 & 280.0 & 33.4 & 170.3 & 0.78 & 1.75 & 0.15 \\
\hline EO & 5.04 & 0.120 & 215.9 & 35.2 & 165.0 & 0.73 & 1.79 & 0.21 \\
\hline EP & 5.60 & 0.129 & 210.8 & 29.2 & 212.7 & 0.54 & 1.44 & 0.21 \\
\hline Notation & $\begin{array}{c}\text { DOC } \\
\left(\mu \mathrm{g} \mathrm{g}^{-1}\right)\end{array}$ & $\begin{array}{c}\mathrm{MBC} \\
\left(\mu \mathrm{g} \mathrm{g}^{-1}\right)\end{array}$ & $\begin{array}{c}\mathrm{MBN} \\
\left(\mu \mathrm{g} \mathrm{g}^{-1}\right)\end{array}$ & $\begin{array}{l}\text { DHA } \\
\left.\lg \operatorname{TPF}^{-1} h^{-1}\right)\end{array}$ & $\begin{array}{c}\text { PME } \\
(\mu \mathrm{g} p \text {-nitrophenol } \\
\left.\mathrm{g}^{-1}\right)\end{array}$ & $\begin{array}{l}\text { FDA } \\
(\mu \mathrm{g} \text { fluorescein } \\
\left.\mathrm{g}^{-1} \mathrm{~h}^{-1}\right)\end{array}$ & $\begin{array}{c}\mathrm{AS} \\
(\mu \mathrm{g} p \text {-nitrophenol } \\
\left.\mathrm{g}^{-1} \mathrm{~h}^{-1}\right)\end{array}$ & $\begin{array}{c}\text { BGLU } \\
(\mu \mathrm{g} p \text {-nitrophenol } \\
\left.\mathrm{g}^{-1} \mathrm{~h}^{-1}\right)\end{array}$ \\
\hline $\mathrm{AF}$ & 2401.7 & 3005.0 & 99.5 & 0.50 & 75.98 & 26.74 & 5.99 & 35.40 \\
\hline $\mathrm{AO}$ & 3031.3 & 3120.0 & 97.8 & 0.22 & 58.89 & 46.49 & 3.90 & 21.36 \\
\hline EA & 1243.6 & 3401.6 & 80.4 & 0.43 & 110.11 & 25.70 & 10.01 & 22.68 \\
\hline $\mathrm{EF}$ & 1809.2 & 4370.0 & 91.8 & 1.32 & 103.87 & 52.44 & 9.19 & 22.81 \\
\hline EO & 1607.0 & 3974.5 & 115.4 & 0.86 & 100.90 & 49.22 & 15.11 & 31.11 \\
\hline EP & 2799.4 & 4494.7 & 130.5 & 1.11 & 115.19 & 44.88 & 9.77 & 45.33 \\
\hline
\end{tabular}

EC, Electrical conductivity; OC, Oxidizable organic carbon; TOC, Total organic carbon; LC, Labile carbon; DOC, Dissolved organic carbon; MBC, Microbial biomass carbon; MBN, Microbial biomass nitrogen; DHA, Dehydrogenase activity; PME, Acid phosphomonoesterase activity; FDA, Fluoroscein diacetate hydrolase; AS, Aryl sulphatase; BGLU, $\beta$-glucosidase.

Oxidizable organic carbon and TOC were determined by wet digestion method ${ }^{23}$ and $0.4 \mathrm{~N}$ chromic acid oxidation in the presence of external heat supply ${ }^{24}$ respectively. $\mathrm{LC}$ was estimated by oxidizing with $333 \mathrm{mM} \mathrm{\textrm {KMnO } _ { 4 }}$ (ref. 25). Soil MBC was measured by modified chloroform fumigation-extraction method with fumigation at atmospheric pressure ${ }^{26}$. Dissolved organic carbon (DOC) was determined after $0.5 \mathrm{~mol} \mathrm{l}^{-1} \mathrm{~K}_{2} \mathrm{SO}_{4}$ solution extraction in unfumigated soil samples ${ }^{27}$. Dehydrogenase (DHA) activity was determined by reduction of 2,3,5triphenyltetrazolium chloride (TTC) ${ }^{28}$. Fluorescein diacetate (FDA) hydrolysis activity measurements were made following the method of Adam and Duncan ${ }^{29}$. Acid phosphomonoesterase (PME) activity was assessed following Tabatabai $^{30}$, with modifications suggested by Schinner et $a l .{ }^{31}$. Aryl sulphatase (AS) and $\beta$-glucosidase (BGLU) activity was assessed following Tabatabai ${ }^{30}$, and Eivazi and Tabatabai ${ }^{32}$ respectively.

\section{Statistical analysis}

Treatments comprised of six types of land-use systems (AF, AO, EA, EF, EO and EP) and four temperature levels (ambient, $36^{\circ} \mathrm{C}, 39^{\circ} \mathrm{C}$ and $42^{\circ} \mathrm{C}$ ) replicated thrice for the analysis of variance under factorial complete randomized design (CRD) to test differences among the treatment means using MSTATC software. Treatment means were compared at the $P<0.05$ level using LSD range test for all the parameters and correlation coefficients were computed using SPSS program (SPSS version 16.0).

\section{Results and discussion}

\section{Effect of elevated incubation temperature on soil chemical properties and fertility}

Wide variability in soil $\mathrm{pH}$ existed among the collected soil samples from different land-use systems incubated under elevated temperature treatment. The $\mathrm{pH}$ of soilwater suspension ranged from 3.9 to 5.7 at ambient (AM, $27^{\circ} \mathrm{C}$ ), 3.8 to 5.3 at maximum temperature (MT, $36^{\circ} \mathrm{C}$ ), 3.8 to 6.0 at $39^{\circ} \mathrm{C}$ and 4.2 to 5.8 at $42^{\circ} \mathrm{C}$ respectively. The highest $\mathrm{pH}$ was about 6.0 in $\mathrm{EO}$ at $39^{\circ} \mathrm{C}$, which is statistically similar $(P<0.05)$ to $\mathrm{pH}$ of $\mathrm{EP}$ at $39^{\circ} \mathrm{C}$, EO at $42^{\circ} \mathrm{C}$ and EP at $39^{\circ} \mathrm{C}$ (Figure $1 \mathrm{a}$ ). No significant difference $(P<0.05)$ in acidity existed among the soil samples 

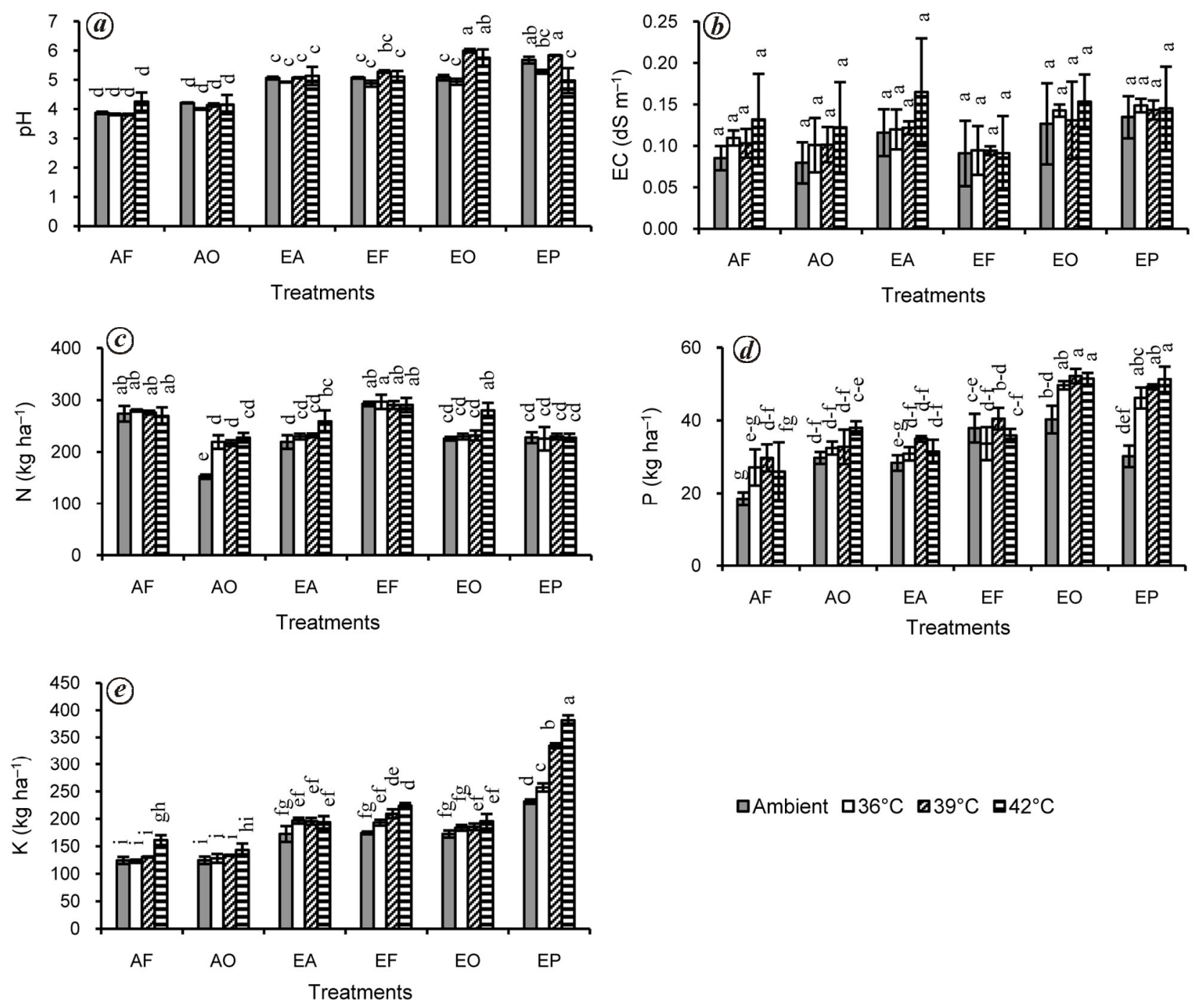

aAmbient $\square 36^{\circ} \mathrm{C} \square 39^{\circ} \mathrm{C} \square 42^{\circ} \mathrm{C}$

Figure 1. Effect of elevated incubation temperature on $(\boldsymbol{a}) \mathrm{pH},(\boldsymbol{b})$ electrical conductivity $\left(\mathrm{EC}, \mathrm{dS} \mathrm{m}^{-1}\right),(\boldsymbol{c})$ available nitrogen $\left(\mathrm{N}, \mathrm{kg} \mathrm{ha}^{-1}\right)$, $(\boldsymbol{d})$ available phosphorus $\left(\mathrm{P}, \mathrm{kg} \mathrm{ha}^{-1}\right)$ and $(\boldsymbol{e})$ available potassium $\left(\mathrm{K}, \mathrm{kg} \mathrm{ha}^{-1}\right)$ of soils collected from different land-use systems.

collected from AF, AO and EA systems. By averaging out the effect of temperature, we observed the highest $\mathrm{pH}$ (5.44) in EO and EP systems (Table 2). However, Alfisol was more acidic than Entisol for all the elevated temperature treatments. We observed no significant change in soil $\mathrm{pH}$ among the treatments with increase in incubation temperature for both the soil groups. EC ranged from 0.080 to $0.135 \mathrm{dS} \mathrm{m}^{-1}$ at $\mathrm{AM}, 0.095$ to $0.149 \mathrm{dS} \mathrm{m}^{-1}$ at $36^{\circ} \mathrm{C}, 0.094$ to $0.143 \mathrm{dS} \mathrm{m}^{-1}$ at $39^{\circ} \mathrm{C}$ and 0.091 to $0.165 \mathrm{dS} \mathrm{m}^{-1}$ at $42^{\circ} \mathrm{C}$ (Figure $1 \mathrm{~b}$ ). We observed no significant difference $(P<0.05)$ in EC values among the treatments, preferably due to their high variation among the treatment replications. However, four land-use systems, namely AF (28.5-54.7\%), AO (26.8-54.0\%), EA (3.4$42.2 \%)$ and EO (3.4-21.2\%) showed an increase in EC values with increase in incubation temperature over ambient.

Increase in incubation temperature increased the release of available nutrients. However the effect was not universal, but depended on the ecosystem health and sea$\operatorname{son}^{33}$. For the three land-use systems, viz. AF, EF and $\mathrm{EP}$, available $\mathrm{N}$ content remained unchanged. The increase in soil available $\mathrm{N}$ content (by 1.85-49.32\%) was significant $(P<0.05)$ with the increase in incubation temperature for soils collected from orchards (AO and EO) and agriculture (EA) land use (Figure $1 c$ ). Probably, the addition of external inputs (fertilizers and manures) in soils under orchards and agriculture land use promoted more organic matter decomposition and mineralization of organic nitrogen through rhizosphere priming effect ${ }^{34}$. By averaging the effect of temperature, the highest available $\mathrm{N}$ was $292.7 \mathrm{~kg} \mathrm{ha}^{-1}$ in EF (Table 2). The enzymes controlling $\mathrm{N}$ cycle will be more active under elevated temperature $^{35}$. Higher enzyme activities related to $\mathrm{N}$-cycling like urease and protease activity in response to warming could be another reason for obtaining such results ${ }^{36}$. This may increase $\mathrm{N}$ mineralization, resulting in an 
Table 2. Effect of increase in temperature on soil fertility, carbon fractions and soil enzyme activities (by averaging out the effect of different incubation temperature exposures)

\begin{tabular}{|c|c|c|c|c|c|c|c|}
\hline \multirow[b]{2}{*}{ Parameters } & \multicolumn{6}{|c|}{ Land-use systems } & \multirow{2}{*}{$\begin{array}{c}\mathrm{CD} \\
(P<0.05)\end{array}$} \\
\hline & $\mathrm{AF}$ & $\mathrm{AO}$ & EA & $\mathrm{EF}$ & $\mathrm{EO}$ & EP & \\
\hline \multicolumn{8}{|l|}{ Soil fertility parameters } \\
\hline $\mathrm{pH}$ & $3.94^{\mathrm{c}}$ & $4.13^{c}$ & $5.05^{\mathrm{b}}$ & $5.08^{\mathrm{b}}$ & $5.44^{\mathrm{a}}$ & $5.44^{\mathrm{a}}$ & 0.24 \\
\hline $\mathrm{EC}\left(\mathrm{dS} \mathrm{m} \mathrm{m}^{-1}\right)$ & $0.108^{\mathrm{a}}$ & $0.101^{\mathrm{a}}$ & $0.131^{\mathrm{a}}$ & $0.093^{\mathrm{a}}$ & $0.138^{\mathrm{a}}$ & $0.143^{\mathrm{a}}$ & NS \\
\hline $\mathrm{N}\left(\mathrm{kg} \mathrm{ha}^{-1}\right)$ & $274.9^{\mathrm{b}}$ & $204.4^{\mathrm{d}}$ & $235.2^{\mathrm{c}}$ & $292.7^{\mathrm{a}}$ & $242.0^{\mathrm{c}}$ & $227.9^{c}$ & 15.88 \\
\hline $\mathrm{P}\left(\mathrm{kg} \mathrm{ha}^{-1}\right)$ & $25.35^{\mathrm{d}}$ & $33.28^{\mathrm{bc}}$ & $31.45^{\mathrm{c}}$ & $37.03^{\mathrm{b}}$ & $48.41^{\mathrm{a}}$ & $44.25^{\mathrm{a}}$ & 4.65 \\
\hline $\mathrm{K}\left(\mathrm{kg} \mathrm{ha}^{-1}\right)$ & $134.8^{\mathrm{d}}$ & $132.5^{\mathrm{d}}$ & $189.7^{\mathrm{bc}}$ & $200.2^{\mathrm{b}}$ & $184.3^{\mathrm{c}}$ & $301.3^{\mathrm{a}}$ & 10.73 \\
\hline \multicolumn{8}{|l|}{ Carbon fractions and microbial biomass } \\
\hline 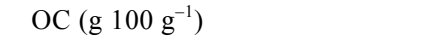 & $0.75^{\mathrm{a}}$ & $0.58^{\mathrm{b}}$ & $0.60^{\mathrm{b}}$ & $0.73^{\mathrm{a}}$ & $0.78^{\mathrm{a}}$ & $0.59^{\mathrm{b}}$ & 0.078 \\
\hline TOC $\left(\mathrm{g} 100 \mathrm{~g}^{-1}\right)$ & $1.17^{\mathrm{a}}$ & $1.14^{\mathrm{a}}$ & $1.22^{\mathrm{a}}$ & $1.18^{\mathrm{a}}$ & $1.24^{\mathrm{a}}$ & $1.17^{\mathrm{a}}$ & NS \\
\hline $\mathrm{LC}\left(\mathrm{g} 100 \mathrm{~g}^{-1}\right)$ & $0.26^{\mathrm{b}}$ & $0.26^{\mathrm{b}}$ & $0.27^{\mathrm{ab}}$ & $0.26^{\mathrm{b}}$ & $0.29^{\mathrm{a}}$ & $0.30^{\mathrm{a}}$ & 0.026 \\
\hline $\mathrm{LT}(\mathrm{wt} \%)$ & $23.18^{\mathrm{b}}$ & $24.92^{\mathrm{ab}}$ & $25.73^{\mathrm{ab}}$ & $24.02^{\mathrm{ab}}$ & $25.81^{\mathrm{ab}}$ & $26.63^{\mathrm{a}}$ & 2.77 \\
\hline $\operatorname{DOC}\left(\mu \mathrm{g} \mathrm{g}^{-1}\right)$ & $1633^{\mathrm{ab}}$ & $1745^{\mathrm{a}}$ & $1068^{\mathrm{c}}$ & $1331^{\mathrm{bc}}$ & $1173^{\mathrm{c}}$ & $1499^{\mathrm{ab}}$ & 299.3 \\
\hline $\operatorname{MBC}\left(\mu g g^{-1}\right)$ & $4231^{\mathrm{c}}$ & $3913^{\mathrm{c}}$ & $4784^{\mathrm{b}}$ & $5346^{\mathrm{a}}$ & $5605^{\mathrm{a}}$ & $5572^{\mathrm{a}}$ & 494.0 \\
\hline $\operatorname{MBN}\left(\mu \mathrm{g} \mathrm{g}^{-1}\right)$ & $140.1^{\mathrm{a}}$ & $113.3^{\mathrm{b}}$ & $141.8^{\mathrm{a}}$ & $166.7^{\mathrm{a}}$ & $159.5^{\mathrm{a}}$ & $140.9^{\mathrm{a}}$ & 34.58 \\
\hline \multicolumn{8}{|l|}{ Soil enzymes } \\
\hline DHA $\left(\mu \mathrm{g} \mathrm{TPF}^{-1} \mathrm{~h}^{-1}\right)$ & $0.793^{\mathrm{d}}$ & $0.518^{\mathrm{f}}$ & $0.668^{\mathrm{e}}$ & $1.799^{\mathrm{a}}$ & $1.163^{\mathrm{c}}$ & $1.354^{\mathrm{b}}$ & 0.058 \\
\hline PME ( $\mu \mathrm{g} p$-nitrophenol $\left.\mathrm{g}^{-1}\right)$ & $74.45^{\mathrm{c}}$ & $63.74^{\mathrm{d}}$ & $101.8^{\mathrm{ab}}$ & $96.45^{\mathrm{ab}}$ & $94.83^{b}$ & $103.6^{\mathrm{a}}$ & 7.62 \\
\hline FDA ( $\mu$ g fluorescein $\mathrm{g}^{-1} \mathrm{~h}^{-1}$ ) & $57.86^{\mathrm{ab}}$ & $58.32^{\mathrm{ab}}$ & $50.94^{\mathrm{c}}$ & $62.94^{\mathrm{a}}$ & $58.82^{\mathrm{ab}}$ & $52.57^{\mathrm{bc}}$ & 6.31 \\
\hline AS $\left(\mu \mathrm{g} p\right.$-nitrophenol $\left.\mathrm{g}^{-1} \mathrm{~h}^{-1}\right)$ & $4.20^{\mathrm{d}}$ & $3.23^{\mathrm{e}}$ & $9.35^{\mathrm{b}}$ & $6.61^{\mathrm{c}}$ & $12.25^{\mathrm{a}}$ & $6.17^{\mathrm{c}}$ & 0.67 \\
\hline BGLU $\left(\mu \mathrm{g} p\right.$-nitrophenol $\left.\mathrm{g}^{-1} \mathrm{~h}^{-1}\right)$ & $84.35^{\mathrm{a}}$ & $73.71^{\mathrm{b}}$ & $35.20^{\mathrm{e}}$ & $43.88^{\mathrm{d}}$ & $61.53^{\mathrm{c}}$ & $59.12^{\mathrm{c}}$ & 5.86 \\
\hline
\end{tabular}

Note: In any single row, means followed by the same letter are not significantly different at $P<0.05$ by DMRT.

increase in available $\mathrm{N}$ content in the soil with increase in incubation temperature. Phorphorus is the most common limiting nutrient element for plants growing in acid soils. Average available $\mathrm{P}$ content over the six land-use systems showed significant increase $(P<0.05)$ with increase in incubation temperature from 30.84 (AM) to $36.68 \mathrm{~kg} \mathrm{ha}^{-1}$ $\left(36^{\circ} \mathrm{C}\right)$; up to $39.96 \mathrm{~kg} \mathrm{ha}^{-1}\left(39^{\circ} \mathrm{C}\right)$, followed by a slight decrease at $42^{\circ} \mathrm{C}\left(39.06 \mathrm{~kg} \mathrm{ha}^{-1}\right)$ (Figure $\left.1 d\right)$. The available $\mathrm{P}$ content was statistically similar in all the elevated incubation temperature treatments (Table 3). By averaging the effect of temperature, available $\mathrm{P}$ was highest for soils collected from EO system $\left(48.41 \mathrm{~kg} \mathrm{ha}^{-1}\right)$ that was statistically similar $(P<0.05)$ to available $\mathrm{P}$ from soils of the EP system $\left(44.25 \mathrm{~kg} \mathrm{ha}^{-1}\right)$ (Table 2). The average change in available $\mathrm{P}$ content was $28.12 \%\left(36^{\circ} \mathrm{C}\right)$, $35.78 \%\left(39^{\circ} \mathrm{C}\right)$ and $34.41 \%\left(42^{\circ} \mathrm{C}\right)$ for Alfisols under different land-use systems (AF and $\mathrm{AO}$ ). The enhancement showed similar pattern, viz. $18.50 \%\left(36^{\circ} \mathrm{C}\right), 30.72 \%$ $\left(39^{\circ} \mathrm{C}\right)$ and $25.91 \%\left(42^{\circ} \mathrm{C}\right)$ for Entisols under the respective land-use systems, viz. EA, EF, EO and EP. Our results were in contrast to the reported decrease $(P<0.05)$ in soil available $P$ content by $18.8 \%$ in the jointing stage of wheat at Taihu Lake region, China, with $+2{ }^{\circ} \mathrm{C}$ temperature elevation over the ambient ${ }^{37}$. At higher temperature (from $39^{\circ} \mathrm{C}$ to $42^{\circ} \mathrm{C}$ ), available $\mathrm{P}$ content was observed to decrease. This may be attributed to the fact that increase in the conversion of weekly bonded $\mathrm{P}$ into strongly bonded forms by elevated incubation temperature ${ }^{38}$. Initial increase in $\mathrm{P}$ content (ambient to elevated) may be due to higher mineralization of organic $P$ induced by increasing temperature ${ }^{38}$. On the contrary, soil warming by $0.8-1.1^{\circ} \mathrm{C}$ over the ambient for short-term (2 years) and long-term (10 years) experiments did not affect soil $\mathrm{pH}$, bulk density, total carbon, nitrogen, phosphorus, organic carbon, available phosphorus, $\mathrm{NO}_{3}-\mathrm{N}, \mathrm{MBC}, \mathrm{MBN}$ and $\mathrm{MBP}$, and cellulase, catalase and phosphatase activities significantly in an alpine meadow ecosystem in QinghaiTibet Plateau (QTP), China ${ }^{39}$.

Although $\mathrm{K}$ is the second most abundant nutrient in plant photosynthetic tissues after $\mathrm{N}$, studies on $\mathrm{K}$ availability with modified temperature regime are rarely reported $^{36}$. The available $\mathrm{K}$ content showed an increasing trend with rise in incubation temperature for all land-use systems considered in the present study (Figure $1 e$ ). However, the average magnitude of increase was significant $(P<0.05)$ for AF $(29.7 \%)$, EF $(28.5 \%)$ and EP $(64.8 \%)$ systems at $42^{\circ} \mathrm{C}$ over the ambient. The highest increase in available $\mathrm{K}$ content was as high as $14.07 \%$ at $36^{\circ} \mathrm{C}$ (EA), $44.68 \%$ at $39^{\circ} \mathrm{C}(\mathrm{EP})$ and 64.84 at $42^{\circ} \mathrm{C}(\mathrm{EP})$ over the ambient. The average increase $(P<0.05)$ in available $\mathrm{K}$ content was $0.75 \%\left(36^{\circ} \mathrm{C}\right), 6.15 \%\left(39^{\circ} \mathrm{C}\right)$ and $22.35 \%$ $\left(42^{\circ} \mathrm{C}\right.$ ) for land use based on Alfisols (AF and $\mathrm{AO}$ ), whereas it was $10.60 \%\left(36^{\circ} \mathrm{C}\right), 21.45 \%\left(39^{\circ} \mathrm{C}\right)$ and $29.77 \%\left(42^{\circ} \mathrm{C}\right)$ for land use based on Entisols (EA, EF, EO and EP). Similarly, the average increase $(P<0.05)$ in available $\mathrm{K}$ was $4.75 \%\left(36^{\circ} \mathrm{C}\right), 12.62 \% \quad\left(39^{\circ} \mathrm{C}\right)$ and $29.10 \%\left(42^{\circ} \mathrm{C}\right)$ over the ambient for Alfisols and Entisols under the forest land-use system and $4.59 \%\left(36^{\circ} \mathrm{C}\right)$, $7.38 \%\left(39^{\circ} \mathrm{C}\right)$ and $14.19 \%\left(42^{\circ} \mathrm{C}\right)$ for orchard soils under Alfisols and Entisols. Also, $42^{\circ} \mathrm{C}$ showed the highest available $\mathrm{K}\left(216.6 \mathrm{~kg} \mathrm{ha}^{-1} ; P<0.05\right)$ by averaging the effect of land-use system (Table 3 ). By averaging the 
Table 3. Effect of increase in temperature on soil chemical properties and fertility, carbon fractions and soil enzyme activities (by averaging out the effect of different land uses)

\begin{tabular}{|c|c|c|c|c|c|}
\hline \multirow[b]{2}{*}{ Parameters } & \multirow[b]{2}{*}{ Ambient } & \multicolumn{3}{|c|}{ Temperature $\left({ }^{\circ} \mathrm{C}\right)$} & \multirow[b]{2}{*}{$\mathrm{CD}(P<0.05)$} \\
\hline & & 36 & 39 & 42 & \\
\hline \multicolumn{6}{|l|}{ Soil fertility parameters } \\
\hline $\mathrm{pH}$ & $4.83^{\mathrm{b}}$ & $4.64^{\mathrm{b}}$ & $5.03^{\mathrm{a}}$ & $4.90^{\mathrm{a}}$ & 0.19 \\
\hline $\mathrm{EC}\left(\mathrm{dS} \mathrm{m} \mathrm{m}^{-1}\right)$ & $0.106^{\mathrm{a}}$ & $0.119^{\mathrm{a}}$ & $0.116^{\mathrm{a}}$ & $0.135^{\mathrm{a}}$ & NS \\
\hline $\mathrm{N}\left(\mathrm{kg} \mathrm{ha}^{-1}\right)$ & $232.1^{\mathrm{b}}$ & $247.0^{\mathrm{a}}$ & $246.4^{\mathrm{a}}$ & $259.2^{\mathrm{a}}$ & 12.97 \\
\hline $\mathrm{P}\left(\mathrm{kg} \mathrm{ha}^{-1}\right)$ & $30.83^{\mathrm{b}}$ & $36.68^{\mathrm{a}}$ & $39.94^{\mathrm{a}}$ & $39.05^{\mathrm{a}}$ & 3.79 \\
\hline $\mathrm{K}\left(\mathrm{kg} \mathrm{ha}^{-1}\right)$ & $166.6^{\mathrm{d}}$ & $180.3^{\mathrm{c}}$ & $198.3^{\mathrm{b}}$ & $216.6^{\mathrm{a}}$ & 8.76 \\
\hline \multicolumn{6}{|l|}{ Carbon fractions and microbial biomass } \\
\hline $\mathrm{OC}\left(\mathrm{g} 100 \mathrm{~g}^{-1}\right)$ & $0.62^{\mathrm{b}}$ & $0.72^{\mathrm{a}}$ & $0.73^{\mathrm{a}}$ & $0.62^{\mathrm{b}}$ & 0.064 \\
\hline $\operatorname{TOC}\left(\mathrm{g} 100 \mathrm{~g}^{-1}\right)$ & $1.56^{\mathrm{a}}$ & $1.25^{\mathrm{b}}$ & $1.09^{c}$ & $0.84^{\mathrm{d}}$ & 0.070 \\
\hline $\mathrm{LC}\left(\mathrm{g} 100 \mathrm{~g}^{-1}\right)$ & $0.20^{\mathrm{d}}$ & $0.29^{\mathrm{b}}$ & $0.35^{\mathrm{a}}$ & $0.26^{\mathrm{c}}$ & 0.021 \\
\hline $\mathrm{LT}(\mathrm{wt} \%)$ & $12.96^{\mathrm{c}}$ & $23.46^{\mathrm{b}}$ & $32.57^{\mathrm{a}}$ & $31.21^{\mathrm{a}}$ & 2.26 \\
\hline $\operatorname{DOC}\left(\mu \mathrm{g} \mathrm{g}^{-1}\right)$ & $2098^{\mathrm{a}}$ & $1397^{\mathrm{b}}$ & $1137^{\mathrm{c}}$ & $1000^{c}$ & 244.4 \\
\hline $\operatorname{MBC}\left(\mu \mathrm{g} \mathrm{g}^{-1}\right)$ & $3901^{\mathrm{d}}$ & $4484^{\mathrm{c}}$ & $5109^{\mathrm{b}}$ & $6140^{\mathrm{a}}$ & 403.3 \\
\hline $\operatorname{MBN}\left(\mu \mathrm{g} \mathrm{g}^{-1}\right)$ & $107.1^{\mathrm{c}}$ & $153.3^{\mathrm{b}}$ & $176.8^{\mathrm{a}}$ & $137.8^{\mathrm{b}}$ & 20.3 \\
\hline \multicolumn{6}{|l|}{ Soil enzymes } \\
\hline DHA $\left(\mu \mathrm{g}\right.$ TPF $\left.g^{-1} h^{-1}\right)$ & $0.83^{\mathrm{c}}$ & $1.01^{\mathrm{b}}$ & $1.18^{\mathrm{a}}$ & $1.18^{\mathrm{a}}$ & 0.05 \\
\hline PME $\left(\mu \mathrm{g} p\right.$-nitrophenol $\left.\mathrm{g}^{-1}\right)$ & $92.56^{\mathrm{a}}$ & $92.14^{\mathrm{a}}$ & $86.63^{\mathrm{ab}}$ & $85.25^{\mathrm{b}}$ & 6.22 \\
\hline FDA ( $\mu$ g fluorescein $\left.\mathrm{g}^{-1} \mathrm{~h}^{-1}\right)$ & $43.88^{\mathrm{c}}$ & $64.64^{\mathrm{a}}$ & $63.81^{\mathrm{a}}$ & $55.30^{\mathrm{b}}$ & 5.15 \\
\hline AS $\left(\mu \mathrm{g} p\right.$-nitrophenol $\left.\mathrm{g}^{-1} \mathrm{~h}^{-1}\right)$ & $8.53^{\mathrm{a}}$ & $7.97^{\mathrm{b}}$ & $7.36^{\mathrm{c}}$ & $4.02^{\mathrm{d}}$ & 0.52 \\
\hline BGLU $\left(\mu \mathrm{g} p\right.$-nitrophenol $\left.\mathrm{g}^{-1} \mathrm{~h}^{-1}\right)$ & $32.96^{\mathrm{d}}$ & $50.59^{\mathrm{c}}$ & $71.96^{\mathrm{b}}$ & $83.02^{\mathrm{a}}$ & 4.78 \\
\hline
\end{tabular}

Note: In any single row, means followed by the same letter are not significantly different at $P<0.05$ by Duncan's multiple range test (DMRT).

effect of incubation temperature, $E P$ had the highest available $\mathrm{K}$ by $301.3 \mathrm{~kg} \mathrm{ha}^{-1}$ (Table 2 ). We did not come across many reports showing how the increase in temperature affects available $\mathrm{K}$ dynamics in the soil-plant system. The increase in incubation temperature might have increased the transformation of non-exchangeable $\mathrm{K}$ into exchangeable $\mathrm{K}$, and thus available $\mathrm{K}$ content (soil solution $\mathrm{K}+$ exchangeable $\mathrm{K}$ ) had increased substantially ${ }^{40}$.

\section{Effect of elevated incubation temperature on carbon fractions and microbial biomass}

Planting trees or perennial crops is an effective option to increase SOC of surface soils ${ }^{41}$. This study evaluated the sensitivity of accumulated organic $\mathrm{C}$ fractions for different land use systems. The SOC content of surface soils was highest for forest lands (Entisols and Alfisols) followed by orchards and pasture land-use system under Entisols. Our results contradict the findings of higher SOC stock for pasture lands followed by forests of northwest India ${ }^{11}$. The increase in incubation temperature increased the organic $\mathrm{C}$ steadily under EA (Figure $2 a$ ). The highest magnitude was $50.75 \%(P<0.05)$ for initial $+3^{\circ} \mathrm{C}$ increase over the maximum in incubation temperature that gradually narrowed down with further increase in incubation temperature level from $45.5 \%\left(36^{\circ} \mathrm{C}\right)$ to $6.5 \%\left(39^{\circ} \mathrm{C}\right)$. For forest soils, incubation at $36^{\circ} \mathrm{C}$ and $39^{\circ} \mathrm{C}$ significantly increased $(P<0.05)$ the organic $\mathrm{C}$ availability, but the trend reversed for $+6^{\circ} \mathrm{C}$ increase over
MT $\left(42^{\circ} \mathrm{C}\right)$. In forest soil, about $12-18.3 \%$ increase $(P<0.05)$ in organic $\mathrm{C}$ content was recorded for Alfisols, while $6.5-6.8 \%$ increase $(P<0.05)$ in organic $\mathrm{C}$ content was recorded for Entisols. Further $+3{ }^{\circ} \mathrm{C}$ rise (i.e. $42^{\circ} \mathrm{C}$ ) in incubation temperature significantly decreased the organic $\mathrm{C}$ availability, even up to the tune of 5.3-15\% for forest soils. However, the net effect was not statistically significant. Irrespective of soil type, orchard soils showed greater stability against the rise in incubation temperature with no significant change in organic $\mathrm{C}$ availability. Our results confirmed the potential of soils to act as a stable sink organic $\mathrm{C}$ under the orchard system $^{42,43}$.

The steady decrease in TOC level with rise in incubation temperature (Figure $2 \mathrm{~b}$ ) that ranged from $4.1 \%$ to $31.4 \%(P<0.05)$ across soil types and land-use systems (except EA), with a concomitant rise in LC fractions that ranged from $21.8 \%$ to $75 \%(P<0.05)$ (Figure $2 c)$. A net increase in $+3{ }^{\circ} \mathrm{C}$ incubation temperature over MT $\left(39^{\circ} \mathrm{C}\right)$ enhanced the magnitude of LC by $33.2-96.6 \%(P<0.05)$, with a significant reduction in soil TOC by $14.6-42.6 \%$ $(P<0.05)$. However, further increase of $+3^{\circ} \mathrm{C}$ incubation temperature $\left(42^{\circ} \mathrm{C}\right)$ reduced $\mathrm{LC}$ content by $34.4-83.5 \%$ and accelerated the loss of soil TOC by $39.4-52.4 \%$ $(P<0.05)$ for different soil type and land-cover system combinations. As a result, the net LC: TOC ratio increased from $29.4 \%$ to $227 \%(P<0.05)$ (Figure $2 d$ ) that was significant while eliminating the effect of land use (Table 3), preferably due to higher temperature sensitivity of stable SOC pool in comparison to $\mathrm{LC}^{44}$. Our results 

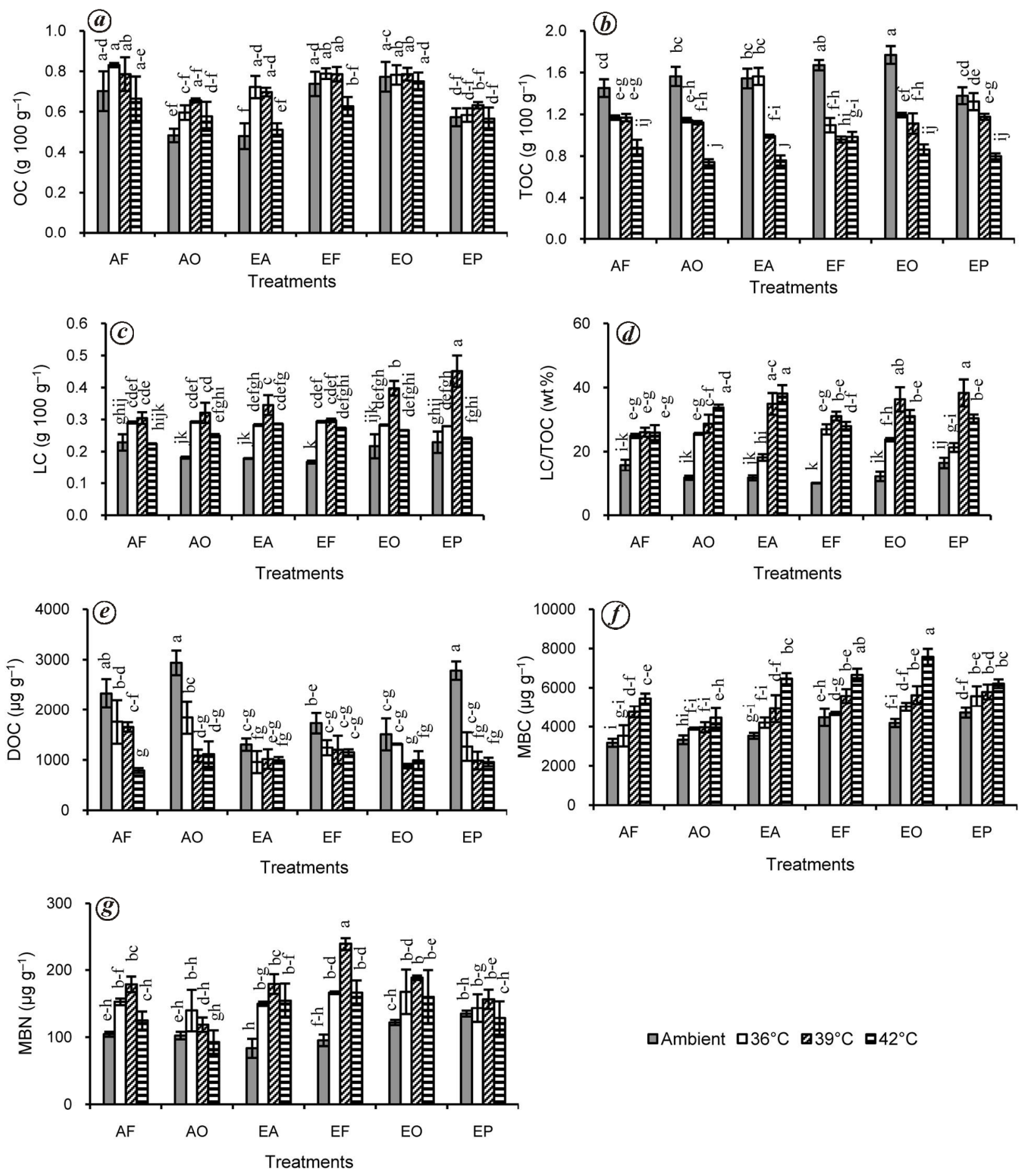

口Ambient $\square 36^{\circ} \mathrm{C} \square 39^{\circ} \mathrm{C} \square 42^{\circ} \mathrm{C}$

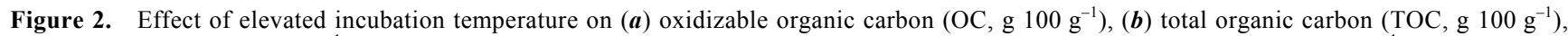
(c) labile carbon (LC, g $\left.100 \mathrm{~g}^{-1}\right),(\boldsymbol{d})$ labile carbon/total organic carbon (LC/TOC, wt\%), (e) dissolved organic carbon (DOC, $\left.\mu \mathrm{g} \mathrm{g} \mathrm{g}^{-1}\right),(\boldsymbol{f})$ microbial biomass carbon (MBC, $\mu \mathrm{g} \mathrm{g}^{-1}$ ), and $(\mathrm{g})$ microbial biomass nitrogen (MBN, $\mu \mathrm{g} \mathrm{g}^{-1}$ ) of soils collected from different land-use systems.

suggest that the decomposition of resistant organic pool is more temperature-sensitive than labile organic mat$\operatorname{ter}^{45,46}$.

With an increase in incubation temperature, a sharp decrease in DOC content was evident for all the land-use system soil samples, considered in the present laboratory incubation study (Figure $2 e$ and Table 3). For MT, the magnitude varied from $12.8 \%$ to $54.5 \%(P<0.05)$ that increased irreversibly with further $+3{ }^{\circ} \mathrm{C}$ and $+6^{\circ} \mathrm{C}$ rise in incubation temperature over MT $(21.8 \%-66 \% ; P<0.05)$. The maximum reduction in soil DOC with increasing incubation temperature was evident for EP $54.5 \%$ for 
$36^{\circ} \mathrm{C} ; 64.5 \%$ for $39^{\circ} \mathrm{C}$ and $65.5 \%$ for $42^{\circ} \mathrm{C}$; significant at $P<0.05$ level) that was preferably due to reduced substrate availability in all the soil samples collected from different land-use systems ${ }^{47}$.

We observed no significant difference between the surface soils of forest and pasture systems. However, significant rise in $\mathrm{MBC}$ was evident in the majority, with elevation of ambient incubation temperature (Figure $2 f$ ). The increase was least for forest soils (EF and AF) with rise in incubation temperature up to $36^{\circ} \mathrm{C}(4.43-11.3 \%$; $P<0.05)$. The magnitude of amplification varied by $19.7-50 \%(P<0.05)$ and $31.7-83 \%(P<0.05)$ for the respective rise in incubation temperature by $3^{\circ}$ and $6^{\circ} \mathrm{C}$ over MT. The significant rise in $\mathrm{MBN}$ varied with increase in incubation temperature over the ambient (Figure $2 \mathrm{~g}$ ). The pasture soil showed least response (increased by $6.1 \% ; P<0.05)$ towards rise in incubation temperature at $36^{\circ} \mathrm{C}$. The trend was maintained for further elevation in incubation temperature level $\left(39^{\circ} \mathrm{C}\right.$ and $\left.42^{\circ} \mathrm{C}\right)$. The highest level of enhanced soil MBN was maintained for $\mathrm{EF}$ $(\sim 100 \%$ increase over the ambient) followed by EA $(\sim 93.2 \%$ increase over the ambient; $P<0.05)$. Increase in $\mathrm{MBC}$ and $\mathrm{MBN}$ at higher temperatures may be due to higher rate of release of substrate from microbes and plant roots ${ }^{48}$. Decrease in $\mathrm{MBN}$ at $42^{\circ} \mathrm{C}$ may be attributed to the death of mesophylls due to thermal denaturation ${ }^{48}$.

\section{Effect of elevated incubation temperature on enzyme activities}

Rise in temperature is generally known to increase enzyme activities ${ }^{49}$, as was the case in this study. Increase in incubation temperature may affect the overall and relative rate of enzyme production due to effects on enzyme efficiency, substrate availability and microbial efficiency. Thus, changes in soil environment will affect the enzyme pool size. In response to the increased activity of existing enzyme pools as soil temperature increases with given available substrate, microbes may allocate fewer resources to enzyme production if microbial biomass remains unchanged ${ }^{50}$. In our experiment, dehydrogenase activity increased significantly with increase in incubation temperature from AM $\left(0.83 \mu \mathrm{g} \mathrm{TPF} \mathrm{g}^{-1} \mathrm{~h}^{-1}\right)$ to $36^{\circ} \mathrm{C}$ $\left(1.01 \mu \mathrm{g} \mathrm{TPF} \mathrm{g}^{-1} \mathrm{~h}^{-1}\right), 39^{\circ} \mathrm{C}\left(1.18 \mu \mathrm{g}\right.$ TPF $\left.\mathrm{g}^{-1} \mathrm{~h}^{-1}\right)$ and $42^{\circ} \mathrm{C}\left(1.18 \mu \mathrm{g} \mathrm{TPF} \mathrm{g}^{-1} \mathrm{~h}^{-1}\right)$ (Figure $\left.3 a\right)$. However, dehydrogenase activities at $39^{\circ} \mathrm{C}$ and $42^{\circ} \mathrm{C}$ were statistically similar (Table 3 ). The average dehydrogenase activity in Alfisols increased by $35.92 \%$ at $36^{\circ} \mathrm{C}, 113.06 \%$ at $39^{\circ} \mathrm{C}$ and $118.96 \%$ at $42^{\circ} \mathrm{C}$ over the ambient $(P<0.05)$, whereas the extent of increase in dehydrogenase activity was much less in Entisols, viz. $27.50 \%$ at $36^{\circ} \mathrm{C}, 41.12 \%$ at $39^{\circ} \mathrm{C}$ and $32.89 \%$ at $42^{\circ} \mathrm{C}$ over the ambient $(P<0.05)$. The highest dehydrogenase was observed in EF $(1.799 \mu \mathrm{g}$ TPF $g^{-1} h^{-1}$ ) which was significantly superior over rest of the land-use systems (Table 3 ). In accordance with our results, Bhattacharyya et $a l .^{51}$ observed significantly high dehydrogenase activity exposed to elevated temperature environment $\left(+2{ }^{\circ} \mathrm{C}\right.$ higher compared to the ambient chamber).

On the contrary, acid phosphomonoesterase activity was $92.56 \mu \mathrm{g} p$-nitrophenol $\mathrm{g}^{-1} \mathrm{~h}^{-1}$ at $\mathrm{AM}, 92.14 \mu \mathrm{g} p$ nitrophenol $\mathrm{g}^{-1} \mathrm{~h}^{-1}$ at $36^{\circ} \mathrm{C}, 86.63 \mu \mathrm{g} p$-nitrophenol $\mathrm{g}^{-1} \mathrm{~h}^{-1}$ at $39^{\circ} \mathrm{C}$, and $85.25 \mu \mathrm{g} p$-nitrophenol $\mathrm{g}^{-1} \mathrm{~h}^{-1}$ at $42^{\circ} \mathrm{C}$. Our results clearly showed the reduction of acid phosphomonoesterase activity with increase in incubation temperature (Table 3). However, the decrease was significant $(P<0.05)$ at $42^{\circ} \mathrm{C}$ over AM. Such significant decrease in acid phosphomonoesterase activity at $42^{\circ} \mathrm{C}$ may be due to the increase in kinetic energy of molecules and breaking of the bonds, holding the active amino group under elevated temperatures. Thus the denaturation of enzyme results in loss of enzyme activity. Our results contradict the reported increase in mineralization of organic-P with increase in temperature, which is facilitated by enhanced activities of phosphatase enzymes in wheat rhizosphere ${ }^{52}$. However, the activities of acid phosphomonoesterase were reported to increase with increasing temperature at $0-5 \mathrm{~cm}$ soil depth ${ }^{6}$. The temperature regime selected in the present experiment was much higher than that in previously reported experiments. Average acid phosphomonoesterase activity in Alfisols was reduced by $2.63 \%$ at $39^{\circ} \mathrm{C}$ and $3.03 \%$ at $42^{\circ} \mathrm{C}$ over the ambient $(P<0.05)$, except in MT that showed significant increase $(P<0.05)$ in acid phosphomonoesterase activity by $20.80 \%$ over the ambient (Figure $3 \mathrm{~b}$ ). Average acid phosphomonoesterase activity in Entisols was lower than the ambient in all treatment combinations $\left(6.94 \%\right.$ at $36^{\circ} \mathrm{C}, 7.41 \%$ at $39^{\circ} \mathrm{C}$ and $9.17 \%$ at $42^{\circ} \mathrm{C}$ ). The highest acid phosphomonoesterase activity was observed in EP (103.6 $\mu \mathrm{g} p$ nitrophenol $\left.\mathrm{g}^{-1} \mathrm{~h}^{-1}\right)$ followed by EA $(101.8 \mu \mathrm{g} p$ nitrophenol $\mathrm{g}^{-1} \mathrm{~h}^{-1}$ ) after averaging out the net effect of elevation in incubation temperature (Table 3 ).

Fluorescein diacetate hydrolase activity in soils collected from all land-use systems showed a significant increase $(P<0.05)$ from $43.88 \mu \mathrm{g}$ fluorescein $\mathrm{g}^{-1} \mathrm{~h}^{-1}$ under $\mathrm{AM}$ to $64.64 \mu \mathrm{g}$ fluorescein $\mathrm{g}^{-1} \mathrm{~h}^{-1}$ at $36^{\circ} \mathrm{C}$, that was slightly reduced further to $63.80 \mu \mathrm{g}$ fluorescein $\mathrm{g}^{-1} \mathrm{~h}^{-1}$ at $39^{\circ} \mathrm{C}$ and $55.30 \mu \mathrm{g}$ fluorescein $\mathrm{g}^{-1} \mathrm{~h}^{-1}$ at $42^{\circ} \mathrm{C}$ (Table 3). The effect was statistically non-significant between $36^{\circ} \mathrm{C}$ and $39^{\circ} \mathrm{C}$. The highest increase in fluorescein diacetate hydrolase activity was observed in AF land use, which was $158.24 \%$ at $36^{\circ} \mathrm{C}, 143.74 \%$ at $39^{\circ} \mathrm{C}$ and $78.69 \%$ at $42^{\circ} \mathrm{C}$ over AM (Figure $3 \mathrm{c}$ ). By averaging the effect of elevation in incubation temperature, the highest fluorescein diacetate hydrolase activity was observed as $62.94 \mu \mathrm{g}$ fluorescein $\mathrm{g}^{-1} \mathrm{~h}^{-1}$ under EF that was statistically similar with fluorescein diacetate hydrolase activity under AF, AO and EO systems (Table 3).

Arylsulphatase activity indicates the ability of the soil to degrade sulphur compounds, particularly aromatic sulphur. Like acid phosphomonoesterase activity, the 

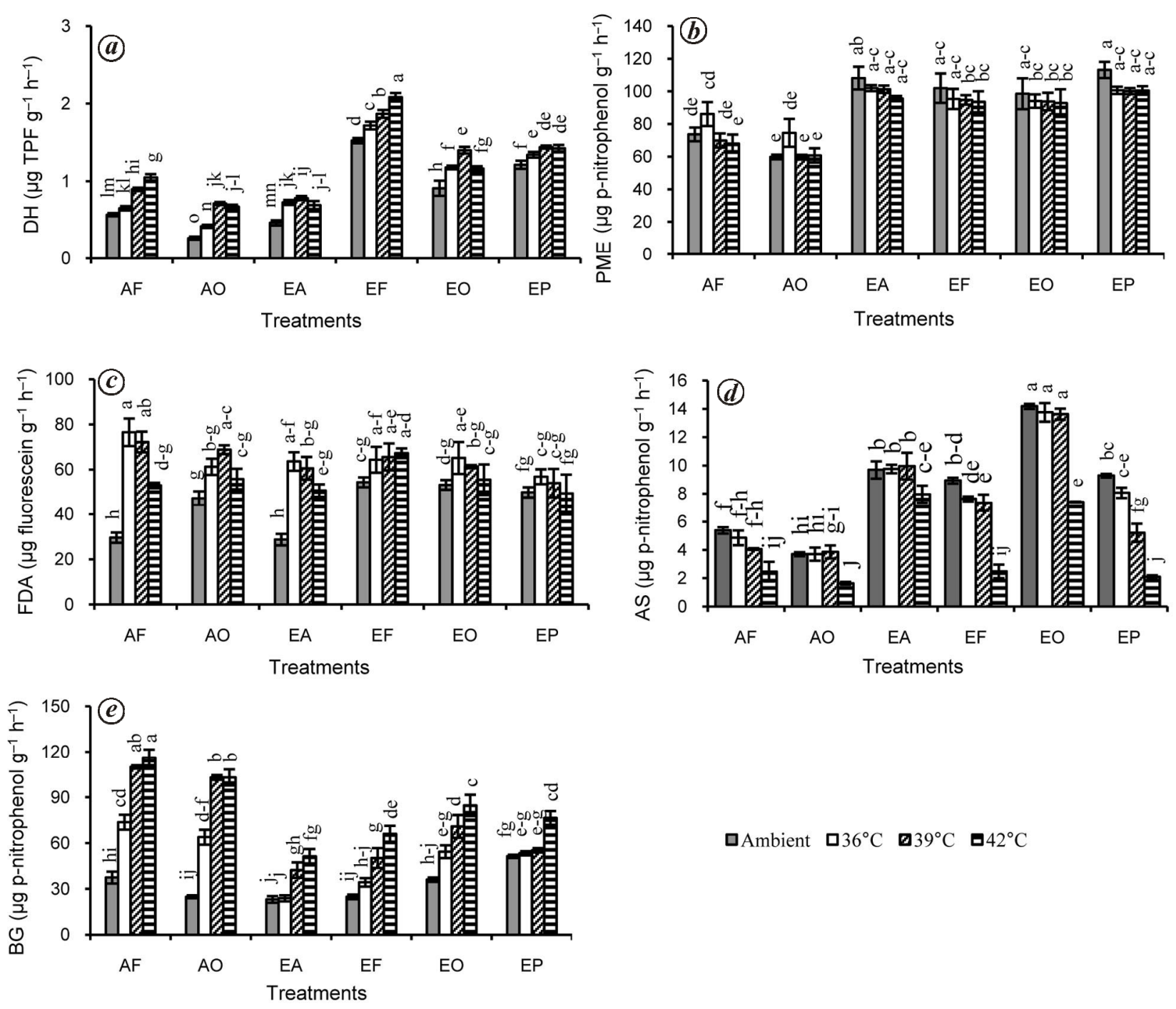

口Ambient $\mathbf{\square} 36^{\circ} \mathrm{C} \quad \mathbf{\square} 39^{\circ} \mathrm{C} \quad \mathbf{\square} 42^{\circ} \mathrm{C}$

Figure 3. Effect of elevated incubation temperature on $(\boldsymbol{a})$ dehydrogenase (DH, $\mu \mathrm{g}$ TPF g $\left.\mathrm{g}^{-1} \mathrm{~h}^{-1}\right),(\boldsymbol{b})$ acid phosphomoesterase (PME, $\mu \mathrm{g}$ $p$-nitrophenol $\mathrm{g}^{-1}$ ), (c) fluorescein diacetate hydrolase (FDA, $\mu \mathrm{g}$ fluorescein $\mathrm{g}^{-1} \mathrm{~h}^{-1}$ ), (d) arylsulphatase (AS, $\mu \mathrm{g} p$-nitrophenol $\mathrm{g}^{-1} \mathrm{~h}^{-1}$ ), (e) $\beta$-glucosidase (BG, $\mu \mathrm{g} p$-nitrophenol $\mathrm{g}^{-1} \mathrm{~h}^{-1}$ ) activity of soils collected from different land-use systems.

decreasing trend was observed for arylsulphatase activity (Figure $3 d$ ). Average arylsulphatase activity of all landuse systems under study varied, viz. $8.53 \mu \mathrm{g} p$ nitrophenol $\mathrm{g}^{-1} \mathrm{~h}^{-1}$ in AM, $7.97 \mu \mathrm{g} p$-nitrophenol $\mathrm{g}^{-1} \mathrm{~h}^{-1}$ at $36^{\circ} \mathrm{C}, 7.35 \mu \mathrm{g} p$-nitrophenol $\mathrm{g}^{-1} \mathrm{~h}^{-1}$ at $39^{\circ} \mathrm{C}$ and $4.02 \mu \mathrm{g} p$-nitrophenol $\mathrm{g}^{-1} \mathrm{~h}^{-1}$ at $42^{\circ} \mathrm{C}$ (Table 3). There was a significant decrease $(P<0.05)$ in arylsulphatase activity by $4.83 \%$ and $7.48 \%$ at $36^{\circ} \mathrm{C} ; 10.02 \%$ and $15.61 \%$ at $39^{\circ} \mathrm{C}$ and $54.76 \%$ and $53.72 \%$ at $42^{\circ} \mathrm{C}$ over AM for Alfisols and Entisols respectively (Figure $3 d$ ). By averaging the net effect of elevation in incubation temperature, the highest arylsulphatase activity was recorded as $12.25 \mu \mathrm{g} p$-nitrophenol $\mathrm{g}^{-1} \mathrm{~h}^{-1}$ in EO, which was significantly superior over arylsulphatase activity in other land-use systems (Table 3).

The $\beta$-glucosidase activity increased significantly $(P<$ $0.05)$ from $32.9 \mu \mathrm{g} p$-nitrophenol $\mathrm{g}^{-1} \mathrm{~h}^{-1}$ in $\mathrm{AM}$ to
$50.59 \mu \mathrm{g} p$-nitrophenol $\mathrm{g}^{-1} \mathrm{~h}^{-1}$ at $36^{\circ} \mathrm{C}, 71.9 \mu \mathrm{g} p$-nitrophenol $\mathrm{g}^{-1} \mathrm{~h}^{-1}$ at $39^{\circ} \mathrm{C}$, and $83.02 \mu \mathrm{g} p$-nitrophenol $\mathrm{g}^{-1} \mathrm{~h}^{-1}$ at $42^{\circ} \mathrm{C}$ (Table 3 ). By averaging the temperature, we observed highest $\beta$-glucosidase activity under in AF system $\left(84.35 \mu \mathrm{g} p\right.$-nitrophenol $\left.\mathrm{g}^{-1} \mathrm{~h}^{-1}\right)$ that was significantly superior over rest of the treatment combinations (Table $2)$. The average $\beta$-glucosidase activity in Alfisols increased by $126.93 \%$ at $36^{\circ} \mathrm{C}, 254.12 \%$ at $39^{\circ} \mathrm{C}$ and $262.65 \%$ at $42^{\circ} \mathrm{C}$ over the ambient $(P<0.05)$, whereas the extent of increase in $\beta$-glucosidase activity was much less in Entisol; $23.95 \%$ at $36^{\circ} \mathrm{C}, 72.23 \%$ at $39^{\circ} \mathrm{C}$ and $117.93 \%$ at $42^{\circ} \mathrm{C}(P<0.05)$ over the ambient (Figure $3 e$ ). The rate of in situ enzyme activity is directly responsive to temperature and moisture ${ }^{6}$. Since we maintained soil moisture at field capacity, hence the increasing effect may be due to the influence of an increase in incubation temperature. Fluorescein diacetate hydrolase and 


\section{RESEARCH ARTICLES}

$\beta$-glucosidase are two important enzymes that play a major role in catalysing the hydrolysis of cellobiose, and thus are involved in the decomposition of organic $\mathrm{C}$ compounds ${ }^{53}$. The concurrent increase in fluorescein diacetate hydrolase (Figure $3 c$ ) and $\beta$-glucosidase (Figure $3 e$ ) activities in the present study was in better agreement with the observed decrease in TOC level (Figure $2 b$ ).

In general, we observed an increase in dehydrogenase, fluorescein diacetate hydrolase and $\beta$-glucosidase activities with increase in incubation temperature. Dehydrogenase and fluorescein diacetate hydrolase represent microbial activities in general, while $\beta$-glucosidase is a carbon-degrading enzyme involved in carbon depolymerization. The probable reason for the increase in enzyme activities may be due to increase in the substrate (e.g. microbial biomass) availability at elevated temperatures $^{48}$. On the contrary, decrease in acid phosphomonoesterase and aryl sulphatase activities may be due to their denaturation at higher temperature. The present study for assessing temperature sensitivity of microbial enzyme activity and associated nutrient dynamics is less biased as the external factors other than temperature influencing SOC decomposition are cut-off. Therefore, the present research findings will provide new insights regarding temperature control on soil $\mathrm{C}$ dynamics and nutrient availability in terms of modified soil enzyme activity. Our results will be useful to model the dynamics of SOM and associated nutrient availability for different existing land-use systems prevailing under the widespread acidic soils in subtropical humid regions of NE India.

1. Chatterjee, D. and Saha, S., Response of soil properties and soil microbial communities to the projected climate change. In $A d$ vances in Crop Environment Interaction (eds Bal, S. et al.) Springer, Singapore, 2018, pp. 87-136.

2. IPCC, Summary for policymakers. In Climate Change 2014: Impacts, Adaptation, and Vulnerability. Part A: Global and Sectoral Aspects. Contribution of Working Group II to the Fifth Assessment Report of the Intergovernmental Panel on Climate Change (eds Field, C. B. et al.), Cambridge University Press, Cambridge, United Kingdom and New York, NY, USA, 2014 pp. $1-32$.

3. Kumar, K. R., Kumar, K. K. and Pant, G. B., Diurnal asymmetry of surface temperature trends over India. Geophys. Res. Lett., 1994, 21, 677-680.

4. Melillo, J., Steudler, P., Aber, J., Newkirk, K., Lux, H. and Bowles, F., Soil warming and carbon-cycle feedbacks to the climate system. Science, 2002, 298, 2173-2176.

5. Stone, M. M. et al., Temperature sensitivity of soil enzyme kinetics under N-fertilization in two temperate forests. Global. Change Biol., 2012, 18, 1173-1184.

6. Steinweg, J. M., Dukes, J. S. and Wallenstein, M. D., Modeling the effects of temperature and moisture on soil enzyme activity: linking laboratory assays to continuous field data. Soil Biol. Biochem., 2012, 55, 85-92.

7. Majumder, B. et al., Organic amendments influence soil organic carbon pools and rice-wheat productivity. Soil Sci. Soc. Am. J., 2008, 72, 775

8. Wall, G. W., McLain, J. E. T., Kimball, B. A., White, J. W., Ottman, M. J. and Garcia, R. L., Infrared warming affects intrarow soil carbon dioxide efflux during vegetative growth of spring wheat. Agron. J., 2013, 105, 607.

9. Rabbi, S. M. F. et al., The relationships between land uses, soil management practices, and soil carbon fractions in South Eastern Australia. Agric. Ecosyst. Environ., 2014, 197, 41-52.

10. Shrestha, B. M., Sitaula, B. K., Singh, B. R. and Bajracharya, R. M., Soil organic carbon stocks in soil aggregates under different land use systems in Nepal. Nutr. Cycling Agroecosyst., 2004, 70, 201-213.

11. Saha, D., Kukal, S. S. and Sharma, S., Landuse impacts on SOC fractions and aggregate stability in typic ustochrepts of Northwest India. Plant Soil, 2011, 339, 457-470.

12. Kong, X., Zhang, F., Wei, Q., Xu, Y. and Hui, J., Influence of land use change on soil nutrients in an intensive agricultural region of North China. Soil Tillage Res., 2006, 88, 85-94.

13. Zeidler, J., Hanrahan, S. and Scholes, M., Land-use intensity affects range condition in arid to semi-arid Namibia. J. Arid Environ., 2002, 52, 389-403.

14. Acosta-Martínez, V., Cruz, L., Sotomayor-Ramírez, D. and PérezAlegría, L., Enzyme activities as affected by soil properties and land use in a tropical watershed. Appl. Soil Ecol., 2007, 35, 35-45.

15. Mganga, K. Z., Razavi, B. S. and Kuzyakov, Y., Land use affects soil biochemical properties in Mt. Kilimanjaro region. CATENA, 2016, 141, 22-29.

16. Liu, X.-L. et al., Impact of land use and soil fertility on distributions of soil aggregate fractions and some nutrients. Pedosphere, 2010, 20, 666-673.

17. Hazarika, S., Soil health management in the context of climate change. In Resource Conservation Technologies in the Context of Climate Change (eds Chatterjee, D. et al.), ICAR Research Complex for NEH Region, Nagaland Centre, Medziphema, 2015, pp. 18-22.

18. Rounsevell, M. D. A. and Reay, D. S., Land use and climate change in the UK. Land Use Policy, 2009, 26, S160-S169.

19. Subbiah, B. and Asija, G., A rapid procedure for assessment of available nitrogen in soils. Curr. Sci., 1956, 25, 259-260.

20. Bray, R. H. and Kurtz, L. T., Determination of total, organic, and available forms of phosphorus in soils. Soil Sci., 1945, 59, 3946.

21. Murphy, J. and Riley, J. P., A modified single solution method for the determination of phosphate in natural waters. Anal. Chim. Acta, 1962, 27, 31-36.

22. Hanway, J. and Hiedal, H., Soil analysis method used in Iowa State Soil Testing Laboratory. Iowa Agric., 1952, 57, 1-31.

23. Walkley, A. and Black, I. A., An examination of the degtjareff method for determining soil organic matter, and a proposed modification of the chromic acid titration method. Soil Sci., 1934, 37, 29-38.

24. Schollenberger, C. J., A rapid approximate method for determining soil organic matter. Soil Sci., 1927, 24, 65-68.

25. Blair, G., Lefroy, R. and Lisle, L., Soil carbon fractions based on their degree of oxidation, and the development of a carbon management index for agricultural systems. Aust. J. Agric. Res., $1995,46,1459$.

26. Witt, C., Gaunt, J. L., Galicia, C. C., Ottow, J. C. G. and Neue, H.-U., A rapid chloroform fumigation-extraction method for measuring soil microbial biomass carbon and nitrogen in flooded rice soils. Biol. Fertil. Soils, 2000, 30, 510-519.

27. Joergensen, R. G., Mueller, T. and Wolters, V., Total carbohydrates of the soil microbial biomass in $0.5 \mathrm{M} \mathrm{K}_{2} \mathrm{SO}_{4}$ soil extracts. Soil Biol. Biochem., 1996, 28, 1147-1153.

28. Casida, L. E., Klein, D. A. and Santoro, T., Soil dehydrogenase activity. Soil Sci., 1964, 98, 371-376.

29. Adam, G. and Duncan, H., Development of a sensitive and rapid method for the measurement of total microbial activity using fluorescein diacetate (FDA) in a range of soils. Soil Biol. Biochem., 2001, 33, 943-951. 
30. Tabatabai, M. A., Soil enzymes. In Methods of Soil Analysis. Part 2. Chemical and Microbiological Properties (eds Page, A. L., Miller, R. H. and Keeney, D. R.), Soil Science Society of America, Madison, Wiscousin, USA, 1982, pp. 903-947.

31. Schinner, F., Kandeler, E. and Margesin, R., Methods in Soil Biology (eds Schinner, F. et al.), Springer, Berlin, Germany, 1996.

32. Eivazi, F. and Tabatabai, M. A., Glucosidases and galactosidases in soils. Soil Biol. Biochem., 1988, 20, 601-606.

33. Lukac, M., Calfapietra, C., Lagomarsino, A. and Loreto, F., Global climate change and tree nutrition: effects of elevated $\mathrm{CO}_{2}$ and temperature. Tree Physiol., 2010, 30, 1209-1220.

34. Pendall, E. et al., Below-ground process responses to elevated $\mathrm{CO}_{2}$ and temperature: a discussion of observations, measurement methods, and models. New Phytol., 2004, 162, 311-322.

35. Megan Steinweg, J., Dukes, J. S., Paul, E. A. and Wallenstein, M. D., Microbial responses to multi-factor climate change: effects on soil enzymes. Front. Microbiol., 2013, 4, 1-11.

36. Sardans, J. and Peñuelas, J., Potassium: a neglected nutrient in global change. Global Ecol. Biogeogr., 2015, 24, 261-275.

37. Zhang, Y., Chen, X., Zhang, C., Pan, G. and Zhang, X. Availability of soil nitrogen and phosphorus under elevated $\left[\mathrm{CO}_{2}\right]$ and temperature in the Taihu Lake region, China. J. Plant Nutr. Soil Sci., 2014, 177, 343-348.

38. Silveira, M. L. and O'Connor, G. A., Temperature effects on phosphorus release from a biosolids-amended soil. Appl. Environ. Soil Sci., 2013, 2013.

39. Wang, X. et al., Effects of short-term and long-term warming on soil nutrients, microbial biomass and enzyme activities in an alpine meadow on the Qinghai-Tibet Plateau of China. Soil Biol. Biochem., 2014, 76, 140-142.

40. Hunsigi, G., Soil temperature and nutrient availability. Ann. Arid Zone, 1975, 14, 87-91.

41. Lal, R., Restoring soil quality to mitigate soil degradation. Sustainability, 2015, 7, 5875-5895.

42. Gama-Rodrigues, E. F., Ramachandran Nair, P. K., Nair, V. D., Gama-Rodrigues, A. C., Baligar, V. C., and Machado, R. C. R., Carbon storage in soil size fractions under two Cacao Agroforestry Systems in Bahia, Brazil. Environ. Manage., 2010, 45, 274-283.

43. Noponen, M. R. A., Healey, J. R., Soto, G. and Haggar, J. P., Sink or source-the potential of coffee agroforestry systems to sequester atmospheric $\mathrm{CO}_{2}$ into soil organic carbon. Agric. Ecosyst. Environ., 2013, 175, 60-68.
44. von Lützow, M. and Kögel-Knabner, I., Temperature sensitivity of soil organic matter decomposition - what do we know? Biol. Fertil. Soils, 2009, 46, 1-15.

45. Hartley, I. P. and Ineson, P., Substrate quality and the temperature sensitivity of soil organic matter decomposition. Soil Biol. Biochem., 2008, 40, 1567-1574.

46. Curiel Yuste, J., Ma, S. and Baldocchi, D. D., Plant-soil interactions and acclimation to temperature of microbial-mediated soil respiration may affect predictions of soil $\mathrm{CO}_{2}$ efflux. Biogeochemistry, 2010, 98, 127-138.

47. Allison, S. D., Wallenstein, M. D. and Bradford, M. A., Soilcarbon response to warming dependent on microbial physiology. Nature Geosci., 2010, 3, 336-340.

48. Joergensen, R. G., Brookes, P. C. and Jenkinson, D. S., Survival of the soil microbial biomass at elevated temperatures. Soil Biol. Biochem., 1990, 22, 1129-1136.

49. Koch, O., Tscherko, D. and Kandeler, E., Temperature sensitivity of microbial respiration, nitrogen mineralization, and potential soil enzyme activities in organic alpine soils. Global Biogeochem. Cycles, 2007, 21, GB4017.

50. Allison, S. D. and Vitousek, P. M., Responses of extracellular enzymes to simple and complex nutrient inputs. Soil Biol. Biochem., 2005, 37, 937-944.

51. Bhattacharyya, P. et al., Influence of elevated carbon dioxide and temperature on belowground carbon allocation and enzyme activities in tropical flooded soil planted with rice. Environ. Monit. Assess., 2013, 185, 8659-8671.

52. Manoj-Kumar, Swarup, A., Patra, A. K., Purakayastha, T. J., Manjaiah, K. M. and Rakshit, R., Elevated $\mathrm{CO}_{2}$ and temperature effects on phosphorus dynamics in rhizosphere of wheat (Triticum aestivum L.) grown in a typic haplustept of subtropical India. Agrochimica, 2011, 55, 314-331.

53. Das, S., Bhattacharyya, P. and Adhya, T. K., Interaction effects of elevated $\mathrm{CO}_{2}$ and temperature on microbial biomass and enzyme activities in tropical rice soils. Environ. Monit. Assess., 2011, 182, $555-569$.

ACKNOWLEDGEMENT. This research was supported by the National Innovations in Climate Resilient Agriculture (NICRA) project of the India Council of Agricultural Research, New Delhi.

Received 31 May 2018; accepted 12 March 2019

doi: $10.18520 / \mathrm{cs} / \mathrm{v} 116 / 112 / 2044-2054$ 